\title{
Analysis of Sales Predictions from the Point of View of the Increase in Daily Newspaper
} Sales

\author{
Rahis Rahman ${ }^{1}$, Mehmood Faheem ${ }^{1}$, Zeda Peerzada \\ ${ }^{1}$ Department of Economics, University of Karachi, Pakistan
}

Received: March 12, 2021

Revised: April 2, 2021

Accepted: April 20, 2021

\begin{abstract}
This study aims at Analysis of Sales Predictions from the Point of View of the Increase in Daily Newspaper Sales. The methods of this research is gather evidence through a variety of approaches, including library analysis and field research. This paper makes use of both qualitative and quantitative evidence. Primary data sources, namely data collected from respondents or direct interviews with business executives, specifically about marketing strategies, especially those relating to promotion. Secondary evidence. Promotional operations are carried out optimally, which is facilitated by sufficient costs, especially in potential areas. Apart from repeat buyers, the organization offers its goods in store, which enables the company to monitor its output figures accurately and seamlessly.
\end{abstract}

Keywords: Promotional Operations, Company, Newspaper Sales

\section{Introduction}

In general, the aim of a business is to earn a certain amount of profit in order to sustain the business's continuity and development. To accomplish this aim, all internal operations and current roles must operate smoothly and be under supervision. Promotion is one of the roles that decides a company's competitiveness in today's business environment, where success cannot be divorced from the expense of promotion (Edwards \& Tsouros, 2006; Kaplan et al., 2001). AYX Media Ltd. New City, as one of the print media outlets dedicated to informing the public, has aided in the advancement of human interests and needs, especially in South New City, and its growth has given knowledge in tandem with the advancement of the times.

Along with the times, the demand for information is extremely high, which is undoubtedly beneficial for all businesses, especially those engaged in publishing, such as Media AYX Ltd. through him, it should be AYX Media Ltd. establishing a reputation among readers by providing and presenting accurate, precise, and reliable information, as well as interesting articles in published editions. One of modern society's basic needs is information, which includes news and entertainment. As a result, AYX daily newspaper, which has a sizable market share, tries to present news according to the preferences of its audience, which is AYX Media Ltd., must incur expenses or make financial sacrifices in the context of promotional activities in order to increase the sales value of its products. A promotion strategy is one of the policies in the marketing mix that is no less important in achieving the company's overall marketing objectives (Constantinides, 2002; O'Cass \& Julian, 2003; Constantinides, 2006; Leonidou et al., 2002). As a result, the author's discussion focuses exclusively on advertising expenses, which are critical to the success of the company. AYX Media Ltd. based in New City, is a business that specializes in delivering information through newspapers, or what is referred to as a newspaper. To compete effectively in revenue, the corporation must follow an advertising campaign. Promotional practices are designed to improve a company's revenue and market share. This is accomplished by direct contact with customers that focuses on their 
desires, including taste, satisfaction, and other factors that serve as guidance or guidelines when performing marketing.

Each business makes an attempt to promote itself as part of its marketing efforts (Hudson \& Ritchie, 2006; Rasmussen et al., 2006). The company uses advertising broadcast via electronic and print media, which is supported by the company's ongoing expenditure of money or potential, including direct promotion labor costs, publication costs, transportation costs, and advertising costs, in order to maximize the promotional activities' effectiveness in increasing the sales value of the product. Failure of a business to market the products is due to a lack of attention to promotional costs to support the smoothness and quality of promotional activities itself, as well as a lack of people familiar with these products, since manufacturers are not only responsible for manufacturing and selling products, but also for introducing and socializing them. According to the explanation above, the writer is involved in selecting the title for this paper, which is to forecast a rise in the AYX Daily Newspaper's revenue.

\section{Methods}

The writers of this paper performed research on Media AYX Ltd., a company based in Jalan Racing Center New City. The duration of the study was roughly two (2) months. The authors gather evidence for this proposal through a variety of approaches, including library analysis and field research. This paper makes use of both qualitative and quantitative evidence. Primary data sources, namely data collected from respondents or direct interviews with business executives, specifically about marketing strategies, especially those relating to promotion. Secondary evidence, namely written data in the context of promotional policy documentation documents, accompanied by lecture materials collected by the author during the study.

\section{Operational Definition}

Marketing is a social and bureaucratic mechanism through which individuals and groups obtain what they require and want through the production, supply, and sale of valuable products and services. Promotion costs involve any expenses paid by a business in terms of capital and opportunity in order to sell the goods, to persuade and alert customers of the product's advantages in the hopes that they may be moved to purchase the product willingly, which requires publishing / advertisement costs. which is the expense of non-personal stimulation for the purpose of requesting a commodity, service, or print media, or of launching the product / service through radio, television, or stage without compensation from the sponsor. Sales is a business practice that involves peddling the goods it markets in such a manner that customers can easily view them and, through proper positioning and arrangement, the commodity can draw the consumer's interest.

\section{Result and Discussion}

\section{Sales Forecast Analysis}

Table 1. Calculation of Sales Forecast on Media AYX Ltd. New City 2019-2020 (Examplar)

\begin{tabular}{|l|r|r|r|c|}
\hline \multicolumn{1}{|c|}{ Month/Year } & Sales (Y) & X & \multicolumn{1}{c|}{ XY } & $\mathrm{X}^{\mathbf{2}}$ \\
\hline September 2019 & 2,160 & -2 & $-4,320$ & 4 \\
\hline December 2019 & 2,340 & -1 & $-2,340$ & 1 \\
\hline March 2020 & 2,880 & 0 & 0 & 0 \\
\hline June 2020 & 3,240 & 1 & 3,240 & 1 \\
\hline September 2020 & 3,600 & 2 & 7,200 & 4 \\
\hline \multicolumn{1}{|c|}{ Total } & $\sum \mathrm{Y} 14,220$ & $\sum \mathrm{X} 0$ & $\sum \mathrm{XY} 3,780$ & $\sum \mathrm{X}^{2} 10$ \\
\hline
\end{tabular}

Data source: Processed data (2021) 
Based on the description of the importance of sales forecasts, in analyzing sales forecasts, the authors use sales data from 2019 to 2020 (quarterly), as shown in table 3, then to calculate sales forecasts the following formula is used:

$\mathrm{Y}=\mathrm{a}+\mathrm{bx}$

Where $\mathrm{y}=$ sales

$$
\begin{aligned}
& x=\text { year (specified period) } \\
& a=\text { constant } \\
& b=\text { slope }
\end{aligned}
$$

As for obtaining the values a and $b$, the formula is used:

Based on the description of the importance of sales forecasts, in analyzing sales forecasts, the authors use sales data from 2019 to 2020 (quarterly), as shown in table 3, then to calculate sales forecasts the following formula is used:

$$
\mathrm{Y}=\mathrm{a}+\mathrm{bx}
$$

Where $\mathrm{y}=$ sales

$$
\begin{aligned}
& \mathrm{x}=\text { year }(\text { specified period) } \\
& \mathrm{a}=\text { constant } \\
& \mathrm{b}=\text { slope }
\end{aligned}
$$

As for obtaining the values a and $b$, the formula is used:

$$
\begin{aligned}
& \mathrm{a}=\frac{\sum \mathrm{y}}{\mathrm{n}}=\frac{14,220}{5}=2,844 \\
& \mathrm{~b}=\frac{\sum \mathrm{xy}}{\sum \mathrm{x}^{2}}=\frac{3,780}{10}=378
\end{aligned}
$$

So, the equation of the straight line is as follows:

$$
\begin{aligned}
& y=a+b x \\
& y=2,844+378(x)
\end{aligned}
$$

Thus, the sales forecast for the coming quarter can be calculated, as follows:

$\begin{aligned} \text { December } 2019 & =2,844+378(3) \\ & =2,844+1,134 \\ & =3978 \\ \text { March } 2020 & =2844+378(4) \\ & =2844+1,512 \\ \text { June 2020 } & =4,356 \\ \text { y } & =2,844+378(5) \\ & =2,844+1,890 \\ & =4,734 \\ \text { yeptember 2020 } & =2,844+378(6) \\ \text { December 2020 } & =2,844+2,268 \\ & =5,112 \\ & =2,844+378(7) \\ & =2,844+2,646 \\ & =5,490\end{aligned}$

For more details of the results of the calculation of the company's forecast in the future, can be seen in the following table:

Tabel 2. Ramalan Penjualan Koran Harian AYX New City Tahun 2019-2020

\begin{tabular}{|l|l|l|}
\hline No & Month / Year & Sales (Exp) \\
\hline
\end{tabular}




\begin{tabular}{|r|l|r|}
\hline 1. & December 2019 & 3,978 \\
\hline 2. & June 2020 & 4,356 \\
\hline 3. & September 2020 & 4,734 \\
\hline 4. & December 2020 & 5,112 \\
\hline & & 5,490 \\
\hline
\end{tabular}

Data source: (data processed: 2021)

As for looking at the sales trends of AYX Daily newspaper based on sales forecast for 5 quarters can be seen in the chart picture (1) below:

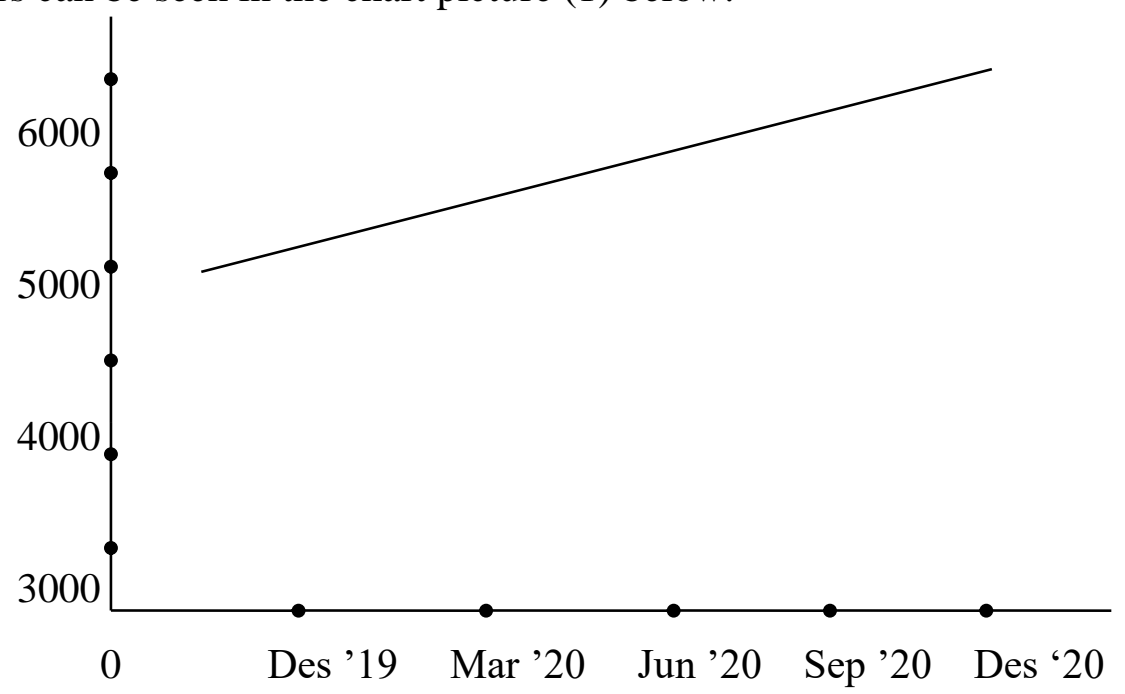

Figure 1. Media AYX Ltd. New City Sales Forecast 2019-2020

According to the findings of the straight-line forecasting process, it is technically possible to conclude that newspaper marketing is here to stay, especially for Media AYX Ltd. New City, which has a very bright future. This is shown in the chart of year-over-year rising pattern values. For the above revenue outlook. The organization should then analyze the different scenarios that could result in revenues, where the prediction would not exclude the company from encountering challenges, necessitating the involvement of all stakeholders in order to achieve the specified targets.

\section{Conclusion}

Promotional operations are carried out optimally, which is facilitated by sufficient costs, especially in potential areas. Apart from repeat buyers, the organization offers its goods in store, which enables the company to monitor its output figures accurately and seamlessly. AYX Media Ltd. New City will raise the appeal of its goods as consumer interest in reading grows, bolstered by the quality of newspapers and the volume of newspaper coverage, as well as the appropriate advertising practices.

\section{References}

Constantinides, E. (2002). The 4S web-marketing mix model. Electronic commerce research and applications, 1(1), 57-76.

Constantinides, E. (2006). The marketing mix revisited: towards the 21 st century marketing. Journal of marketing management, 22(3-4), 407-438.

Edwards, P., \& Tsouros, A. D. (2006). Promoting physical activity and active living in urban environments: the role of local governments. WHO Regional Office Europe. 
Hudson, S., \& Ritchie, J. B. (2006). Promoting destinations via film tourism: An empirical identification of supporting marketing initiatives. Journal of travel research, 44(4), 387-396.

Kaplan, R. S., Robert, N. P. D. K. S., Kaplan, R. S., \& Norton, D. P. (2001). The strategyfocused organization: How balanced scorecard companies thrive in the new business environment. Harvard Business Press.

Leonidou, L. C., Katsikeas, C. S., \& Samiee, S. (2002). Marketing strategy determinants of export performance: a meta-analysis. Journal of Business research, 55(1), 51-67.

O'Cass, A., \& Julian, C. (2003). Examining firm and environmental influences on export marketing mix strategy and export performance of Australian exporters. European journal of marketing.

Rasmussen, E., Moen, Ø., \& Gulbrandsen, M. (2006). Initiatives to promote commercialization of university knowledge. Technovation, 26(4), 518-533. 